\title{
WEAVING LIFE STORIES: HEALING SELVES IN NATIVE AMERICAN AUTOBIOGRAPHICAL NARRATIVES, DE MARTA RAMOS OLIVEIRA $^{1}$
}

Anselmo Peres Alós Universidade Federal de Santa Maria, UFSM, Santa Maria, Brasil

Nesta tese (originalmente redigida em língua inglesa), faz-se uma reflexão sobre as narrativas de vida indígenas a partir da hipótese de que, em contraposiçáo ao modelo canônico ocidental, elas apresentam uma concepçáo de self marcada por um posicionamento social diverso, tanto como experiência histórica quanto de visão epistemológica e ontológica. $\mathrm{O}$ objetivo do trabalho foi mostrar como os escritores indígenas apropriamse de um modelo ocidental - que, na sua configuraçáo canônica, servia para sustentar narrativas de individuação - e utilizam-no para curar feridas históricas resultantes da violência do processo de colonização (e suas consequências) para, com isso, criar possibilidades de sobrevivência coletiva. Com esse propósito, fez-se uma breve revisão de dois períodos fundamentais do desenvolvimento do gênero no Ocidente que, em um primeiro momento, confundem a história da autobiografia com a confissão cristã e, em um momento posterior, com o processo de individuaçáo. Em uma perspectiva mais contemporânea, discute-se a impossibilidade linguística de se falar do eu sem se deparar com uma série de descontinuidades e becos sem saída que parecem impor uma sua fragmentação total, a ponto de se pensar ser impossível dizer o dêitico "eu". A essa visão canônica da história do gênero, contrapóem-se as narrativas indígenas que se valem das histórias de vida como forma de buscar as experiências que lhes dáo sustentação não só como forma de reavaliaçáo do vivido, mas também como abertura para novas possibilidades no futuro. Em um segundo momento, revisa-se a noçáo de tempo ocidental mostrando como, apesar da concomitância de várias cronosofias que definem o tempo como cíclico, linear ou a-direcional, nossas sociedades estruturam-se a partir do modelo de progresso que fundamenta o binômio modernidade/colonialidade. Em outras palavras, a visão linear do tempo aliado ao processo histórico de subjugação dos povos e conquista de territórios estabeleceu um modelo que se autodefine como inovador, ou de ponta, relegando todas as outras formas humanas de organização

\footnotetext{
${ }^{1}$ Tese orientada por Rita Terezinha Schmidt, defendida em 2009, na Universidade Federal do Rio Grande do Sul.
} 
a estágios mais atrasados do mesmo processo. A partir do paradigma de coexistência, são discutidas outras visôes epistemológicas, contrapondo a visão do tempo linear e progressivo à forma como os indígenas concebem o espaço como catalisador das histórias que sustentam as relaçóes indígenas com o Outro. Importante ressaltar que a noção de Outro, usada ao longo da tese, abrange tudo aquilo que está em relação com o eu, incluindo, além dos seres humanos, animais, plantas, rios, a Terra, o Sol, e mesmo entidades não físicas. Finalmente, analisa-se em Storyteller, de Leslie Marmon (1981), como os escritos de vida indígena manifestam esse modo de ser e seu potencial curativo. 